\title{
Detection of Human Herpesvirus-7 DNA in Bronchoalveolar Lavage
}

\author{
Sara Astegiano ${ }^{a}$ Cristina Costa ${ }^{a}$ Maria Elena Terlizzi ${ }^{a} \quad$ Francesca Sidoti $^{a}$ \\ Stefano Gambarino ${ }^{a}$ Samantha Mantovani ${ }^{a}$ Paolo Solidoro $^{\text {b }}$ Rossana Cavallo $^{a}$ \\ Massimiliano Bergallo ${ }^{a}$ \\ aVirology Unit and ${ }^{b}$ Pulmonary Division, University Hospital San Giovanni Battista di Torino, Turin, Italy
}

\section{Key Words}

Human herpesvirus-7 · Real-time PCR $\cdot$ Bronchoalveolar

lavage $\cdot$ Lower respiratory tract infection

\begin{abstract}
Objectives: Human herpesvirus-7 (HHV-7) is a highly seroprevalent virus that, following primary infection, establishes latency or persistence in some tissues, including lung. The aim of this study was to investigate the prevalence of HHV-7 in the lower respiratory tract of hospitalized adult patients. Methods: The prevalence of HHV-7 DNA was determined by quantitative real-time PCR in 212 bronchoalveolar lavage (BAL) samples obtained from 153 patients. The molecular epidemiology and clinical role of HHV-7 were evaluated. Results: HHV-7 DNA was positive in 44 of 212 specimens (20.7\%), obtained from 40 of 153 patients (26.1\%), in particular 22/68 (32.35\%) and 18/86 (20.9\%) in transplant and nontransplant patients, respectively (1 patient evaluated both before and after transplantation). No significant difference according to transplant condition or discharge diagnosis was found. Viral load was $>100,000$ genome equivalents $/ \mathrm{ml}$ BAL in 6/22 (27.3\%) transplant recipients and 4/18 (22.2\%) non-transplant patients ( $p=n . s$.). Conclusions: The evaluation of HHV-7 DNA in BAL may be useful to investigate its
\end{abstract}

potential role in lower respiratory tract infection, alone or in association with other viral and/or non-viral pathogens and to distinguish latency from reactivation.

Copyright $\odot 2009$ S. Karger AG, Basel

\section{Introduction}

Human herpesvirus-7 (HHV-7) is a highly seroprevalent $\beta$-herpesvirus closely related to both human herpesvirus-6 (HHV-6) and cytomegalovirus (HCMV) [1-3]. Primary infection usually occurs in childhood, presumably from saliva and is usually asymptomatic but occasionally causes exanthem subitum, as well it has been associated with pityriasis rosea, hepatitis, neurological manifestations and transplant complications. Subsequently, HHV-7 establishes latency in activated T cells and in some tissues, including lung [4]. The pathogenic role of HHV-7 reactivation in critically ill but otherwise immunocompetent patients is controversial, while it is currently believed that the effects of HHV-7 and HHV-6

S.A. and C.C. contributed equally to this work and share first authorship.

\section{KARGER}

Fax +4161306 1234

E-Mail karger@karger.ch

www.karger.com (c) 2009 S. Karger AG, Basel

$0300-5526 / 10 / 0532-0119 \$ 26.00 / 0$

Accessible online at:

www.karger.com/int
Dr. Cristina Costa, MD

Virology Unit, University Hospital San Giovanni Battista di Torino

Via Santena 9, IT-10126 Turin (Italy)

Tel. +39011 670 5630, Fax +390116705648

E-Mail cristina.costa@unito.it 
reactivation in immunocompromised patients may be mediated by their interaction with HCMV, thus predisposing to the viral syndrome or organ-specific disease caused by HCMV. It has been proposed that HHV-7 may play a role in causing interstitial pneumonia in patients who are not transplant recipients [5] and Ross et al. [6] have supported an association between bronchiolitis obliterans with organizing pneumonia (BOOP) and HHV-7.

The aim of this study was to investigate the prevalence of HHV-7 in bronchoalveolar lavage (BAL) from hospitalized adults by comparing transplant versus non-transplant patients.

\section{Materials and Methods}

Over a full-year period (April 2008-2009), all the $212 \mathrm{BAL}$ specimens from 153 patients $(102 \mathrm{~m} / 51 \mathrm{f}$; mean age \pm SD $56.7 \pm$ 15.3 , range 18-84) whose clinical charts were available were analyzed. Multiple BAL procedures were performed in 37 patients (mean 3.0, range 2-7). Samples from the same patient that were collected less than 2 weeks apart were excluded. Informed consent was obtained from all the patients or the nearest relative. The BAL procedure was performed for investigating the cause of unexplained fever and/or respiratory symptoms (including dyspnea, cough, hemoptysis) and/or new infiltrates on chest X-ray or in the absence of the above-mentioned conditions for checking up a previous positivity or as routine follow-up in lung transplant recipients $(n=25)$ at month 1 post-transplantation and subsequently at 3-month intervals. Combined HCMV prophylaxis after lung transplantation was performed with valganciclovir $(450 \mathrm{mg}$ twice daily) from day 21 after transplantation for 3 weeks associated with HCMV-IG (Cytotect Biotest) at days 1, 4, 8, 15, and 30 $(1.5 \mathrm{ml} / \mathrm{kg}$ b.w. $)$ and every month for 1 year after transplantation ( $1 \mathrm{ml} / \mathrm{kg}$ b.w.) irrespective of HCMV mismatching, as previously described [7]. Ganciclovir or valganciclovir were further administered in case of HCMV-DNA load $>1,000$ genome equivalents $(\mathrm{GEq}) / \mathrm{ml} \mathrm{BAL}$ in lung transplant patients, according to center practice [7], and based on laboratory, radiological, and clinical data in another 9 transplant patients.

Based on the clinical chart review, the following features were recorded: demographic characteristics; underlying pathologies, in particular transplantation, immunological conditions (immunosuppression due to anti-rejection treatment in transplant recipients, chemotherapy, HIV infection or long-term use of corticosteroids); and discharge diagnosis (made according to the International Classification of Diseases - Italian Version 2002, based on the 9th Revision Clinical Modification [ICD9CM], codes 480.XX-486.XX for pneumonia; 460.XX-466.XX for acute respiratory insufficiency or other acute respiratory conditions; 491.21 for acute exacerbations of chronic obstructive pulmonary disease; 490.XX-519.XX for other pneumopathies; 33.22 for bronchoscopy).

BAL procedures were performed as previously described [8]. Automated total nucleic acid extraction was performed with Nuclisens EasyMAG platform (bioMérieux, Marcy l'Etoile, France), according to the manufacturer's instructions. Qualitative detection of nucleic acid of human metapneumovirus [9], bocaviruses [10], and coronaviruses [11] was performed as previously described, as well as TaqMan real-time PCR for HHV-6 [12], enteroviruses [13], rhinoviruses [14], parainfluenza viruses [15], and influenza $A$ and $B$ viruses [16]. For the detection of HCMV-DNA and EBV-DNA, two TaqMan real-time PCR assays were used utilizing commercial kits (Q-CMV Real-Time Complete Kit, Q-EBV, Nanogen Advanced Diagnostics, Milan, Italy), according to the manufacturer's instructions. Real-time quantitative PCR for HHV-7-DNA was performed using a home-made protocol of LUX $^{\mathrm{TM}}$ (Light Upon eXtension), as previously described [17]. Moreover, results from rapid shell vial culture for CMV, herpes simplex virus (HSV) type 1 and 2, respiratory syncytial virus (RSV), adenovirus, parainfluenza viruses, Influenza A and B viruses were evaluated, as previously described [8].

Statistical analysis was performed using the $\chi^{2}$ test and the $t$ test, as appropriate, employing a commercially available software (MedCalc; version 9.2.1.0). A p value $<0.05$ was considered statistically significant.

\section{Results}

Results are summarized in table 1. PCR for HHV-7 was positive in 44 of 212 specimens (20.7\%), obtained from 40 of 153 patients (26.1\%); in particular 22/68 (32.35\%) and 18/86 (20.9\%) in transplant and non-transplant patients, respectively (1 patient was evaluated both before and after transplantation). Considering discharge diagnosis, in the group of transplant recipients, HHV-7 DNA was positive in 5 of 17 patients (29.4\%) with pneumonia, 12/35 (34.2\%) with acute respiratory conditions, $0 / 2(0 \%)$ with acute exacerbations of chronic obstructive pulmonary disease, and 5/14 (35.7\%) in follow-up. In non-transplant patients, HHV-7 DNA was positive in 4/19 (21\%) with pneumonia, 7/36 (19.4\%) with acute respiratory conditions, $1 / 2$ (50\%) with acute exacerbations of chronic obstructive pulmonary disease, and 6/29 (20.7\%) with other underlying pneumopathies. The prevalence of HHV-7 DNA positivity did not significantly differ between the groups $(\mathrm{p}=\mathrm{n} . \mathrm{s})$. Data on co-infections are summarized in table 1. Focusing on HCMV and HHV-6, the presence of co-infection was as follows: 7/22 (31.8\%) HHV-7 + HCMV, 6/22 (27.3\%) HHV-7 + HHV-6 and $3 / 22(13.6 \%)$ HHV-7 + HHV-6 + HCMV in transplant recipients; 5/22 (22.7\%) HHV-7 + HCMV, 1/22 (4.5\%) HHV-7 + HHV-6 and 1/22 (4.5\%) HHV-7 + HHV$6+\mathrm{HCMV}$ in non-transplant patients. The occurrence of co-infections with HCMV did not significantly differ between transplant and non-transplant patients. Moreover, approximately $42.5 \%$ of HHV-7 positive-patients also presented a co-infection with one of the other viruses 
Table 1. Prevalence of HHV-7 DNA positivity and co-infections with HHV-6 and HCMV in the study population

\begin{tabular}{|c|c|c|c|}
\hline Patients & $\begin{array}{l}\text { HHV-7 DNA-positive } \\
\mathrm{n}(\%)\end{array}$ & $\begin{array}{l}\text { HHV-7 DNA-negative } \\
\mathrm{n}(\%)\end{array}$ & $\begin{array}{l}\text { Co-infections } \\
\mathrm{n}(\%)\end{array}$ \\
\hline Transplant & $\begin{array}{l}\text { pneumonia: } 5 / 17(29.4 \%) \\
\text { acute respiratory condition or respiratory } \\
\text { insufficiency: } 12 / 35(34.3 \%) \\
\text { acute exacerbations of COPD: } 0 / 2(0 \%) \\
\text { follow-up: } 5 / 14(35.7 \%)\end{array}$ & $\begin{array}{l}\text { pneumonia: } 12 / 17(70.6 \%) \\
\text { acute respiratory condition or respiratory } \\
\text { insufficiency: } 23 / 35(65.7 \%) \\
\text { acute exacerbations of COPD: } 2 / 2(100 \%) \\
\text { follow-up: } 9 / 14(64.3 \%)\end{array}$ & $\begin{array}{l}\text { HHV }-7 \text { + HHV-6: 6/22 }(27.3 \%) \\
\text { HHV -7 + HCMV: } 7 / 22(31.8 \%) \\
\text { HHV-7 + HHV-6 + HCMV: } 3 / 22(13.6 \%)\end{array}$ \\
\hline $\begin{array}{l}\text { Non- } \\
\text { transplant }\end{array}$ & $\begin{array}{l}\text { pneumonia: } 4 / 19(21 \%) \\
\text { acute respiratory condition or respiratory } \\
\text { insufficiency: } 7 / 36(19.4 \%) \\
\text { acute exacerbations of COPD: } 1 / 2(50 \%) \\
\text { other pneumopathies: } 6 / 29(20.7 \%)\end{array}$ & $\begin{array}{l}\text { pneumonia: } 15 / 19(79 \%) \\
\text { acute respiratory condition or respiratory } \\
\text { insufficiency: } 29 / 36(80.6 \%) \\
\text { acute exacerbations of COPD: } 1 / 2(50 \%) \\
\text { other pneumopathies: } 23 / 29(79.3 \%)\end{array}$ & $\begin{array}{l}\text { HHV }-7 \text { + HHV }-6: \text { 1/22 (4.5\%) } \\
\text { HHV-7 + HCMV: 5/22 (22.7\%) } \\
\text { HHV-7 + HHV-6 + HCMV: 1/22 (4.5\%) }\end{array}$ \\
\hline
\end{tabular}

COPD $=$ Chronic obstructive pulmonary disease.

evaluated (data not shown). Correlation with epidemiologic, clinical, radiological, laboratory, and therapeutic data are summarized in table 2.

Subsequently, we focused our analysis on specimens with a viral load $>100,000 \mathrm{GEq} / \mathrm{ml}$ BAL of HHV-7-DNA. This level was chosen taking into account that HHV-7, similarly to HCMV, latently persists in lung, and that a HCMV load $>100,000 \mathrm{GEq} / \mathrm{ml}$ BAL is suggested as being associated with organ disease in solid organ transplant recipients and a cutoff for preemptive therapy in lung transplant recipients [18]. Viral load was $>100,000 \mathrm{GEq} /$ $\mathrm{ml} \mathrm{BAL}$ in 6/22 (27.3\%) transplant recipients and 4/18 $(22.2 \%)$ non-transplant patients $(\mathrm{p}=\mathrm{n} . \mathrm{s}$.). Clinical characteristics of patients displaying a viral load $>100,000$ $\mathrm{GEq} / \mathrm{ml} \mathrm{BAL}$ are summarized in table 3.

\section{Discussion}

Our study found a $26.1 \%$ prevalence of HHV-7 DNA positivity in hospitalized adult patients; no significant difference in prevalence and viral load was found between transplant and non-transplant patients, or according to discharge diagnosis. Viral load, $>100,000 \mathrm{GEq} / \mathrm{ml}$ BAL in only 11 patients, was low in most of the patients, thus suggesting potential viral latency or minor replicative forms which are not distinguishable by molecular assays. Given the high seroprevalence of HHV-7 in the general population and latency in lung, as well as the concomitant detection of other viral pathogens, it is difficult to demonstrate an association between the virus and lower respiratory tract morbidities [5]. Reactivation is com-
Table 2. Correlation with epidemiologic, clinical and laboratory data

\begin{tabular}{|c|c|c|}
\hline Patients $(\mathrm{n}=153)$ & $\begin{array}{l}\text { HHV-7- } \\
\text { positive } \\
\mathrm{n}(\%)\end{array}$ & $\begin{array}{l}\text { HHV-7- } \\
\text { negative } \\
\text { n (\%) }\end{array}$ \\
\hline \multicolumn{3}{|l|}{ Transplant recipients } \\
\hline Lung (25) & $8(32)$ & $17(68)$ \\
\hline $\begin{array}{c}\text { Hematopoietic stem cell } \\
\text { transplantation (29) }\end{array}$ & $5(17.2)$ & $24(82.8)$ \\
\hline Others (13) & $9(69.2)$ & $4(30.8)$ \\
\hline Death (mortality within 28 days) (20) & $5(25)$ & $15(75)$ \\
\hline Mechanical ventilation (46) & $13(28.3)$ & $33(71.7)$ \\
\hline \multicolumn{3}{|l|}{ Immunological competence } \\
\hline Yes $(31)$ & $6(19.4)$ & $25(80.6)$ \\
\hline No (122) & $28(22.9)$ & $94(77.1)$ \\
\hline Pneumonia (36) & $9(25)$ & $27(75)$ \\
\hline \multicolumn{3}{|l|}{ Age group } \\
\hline$<40$ years old $(23)$ & $5(21.7)$ & $18(78.3)$ \\
\hline $40-60$ years old (54) & $11(20.4)$ & $43(79.6)$ \\
\hline$>60$ years old $(76)$ & $16(21.1)$ & $60(78.9)$ \\
\hline
\end{tabular}

mon in immunocompromised conditions, particularly in the transplant setting, ranging from 53 up to $57 \%$ and from 0 up to $46 \%$ in bone marrow transplant recipients and renal transplant patients, respectively $[19,20]$. It has to be noted that as the dilution of alveolar fluid in BAL may vary considerably, it may be more appropriate to define the detection of viral nucleic acids as a 'semiquantitative' determination. 
Table 3. Clinical characteristics of patients with HHV-7 viral load $>100,000 \mathrm{GEq} / \mathrm{ml}$

\begin{tabular}{llllll}
\hline $\begin{array}{l}\text { Sex/age (years)/ } \\
\text { study group }\end{array}$ & $\begin{array}{l}\text { Immuno- } \\
\text { competence }\end{array}$ & Clinical diagnosis & $\begin{array}{l}\text { HHV-7 } \\
\text { GEq/ml }\end{array}$ & Other infectious pathogens & $\begin{array}{c}\text { Death } \\
<28 \text { days }\end{array}$ \\
\hline M/50/TR (SOT) & no & pneumonia & 226,554 & EBV, HCMV & - \\
F/60/TR (SOT) & no & respiratory failure & 244,442 & EBV, HHV-6, HCMV, HRV & + \\
F/47/TR (SOT) & no & follow-up & 140,501 & HCMV & - \\
M/27/TR (SOT) & no & respiratory failure & 139,140 & & - \\
F/29/TR (HSCT) & no & pneumonia & 202,994 & EBV, HHV-6, & - \\
M/18/TR (SOT) & no & follow-up & 321,289 & & - \\
M/64/NT & no & cirrhosis & 314,043 & & - \\
M/67/NT & yes & respiratory failure & 337,295 & HCMV & - \\
M/62/NT & yes & pneumonia & 687,129 & EBV, HCMV, influenza A virus & - \\
F/49/NT & yes & pneumonia & 222,188 & & - \\
\hline
\end{tabular}

SOT $=$ Solid organ transplantation; HSCT = hematopoietic stem cell transplantation; $\mathrm{TR}=$ transplant; NT = non-transplant; $\mathrm{MV}=$ mechanical ventilation.

The direct manifestation of HHV-7 reactivation posttransplantation is poorly known [21,22]. Considering the relationship between viral reactivation related with $\beta$ herpesviruses occurring after transplantation, several studies have evidenced the development of HCMV disease together with the concomitant reactivation of HHV7, but its role is uncertain [22-25], also taking into consideration the several host- and virus-related factors favoring the development of HCMV disease [26]. In a study on lung transplant recipients, Ross et al. [6] evidenced an association between bronchiolitis obliterans (BO) with organizing pneumonia (BOOP) and HHV-7 DNA positivity in all 7 cases found in a group of 19 graft recipients, although viral load was not evaluated. On the contrary, in a recent study on lung transplant recipients, Manuel et al. [27] noticed that viral replication was not associated with the development of BOS, although high viral loads were present in many patients.

In a recent study on solid organ transplant recipients who underwent treatment for HCMV disease, Humar et al. [20] evidenced that co-infections with HHV-6 and HHV-7 in patients with HCMV disease were common, with low viral load especially for HHV-7, even if a clinical role has not yet been defined; however, in patients with HCMV disease these co-infections have no different effect on the response of HCMV to standard therapy, thus the routine monitoring of these two viruses in patients with HCMV disease is not suggested. Serological status for HHHV-7 and HHV-6 was not available, although we can assume it to be as high as $>75 \%$ [1]. Similarly, given the HCMV epidemiology in Italy and the serological data of transplant patients available in our study, the HCMV seroprevalence was $>75 \%$ and the occurrence of co-infections with HCMV did not significantly differ between transplant and non-transplant patients.

In conclusion, based on our data, the quantitative evaluation of HHV-7 DNA in BAL may be useful to investigate its potential role in lower respiratory tract infection, alone or in co-infection with other pathogens. The occurrence of multiple infections is a common finding and results should be interpreted taking into account the clinical context as well as viral load and the biological characteristics of the virus.

Further studies are required both to define a possible association between HHV-7 and lower respiratory tract infection, and to prevent post-transplantation complications due to $\beta$-herpesviruses.

References

Astegiano et al.
Ward KN: Human herpesviruses- 6 and -7 infections. Curr Opin Infect Dis 2005; 18: 247-252.

- Frenkel N, Schirmer EC, Wyatt LS, Katsafanas G, Roffman E, Danovich RM, June CH: Isolation of a new herpesvirus from human CD4+ T cells. Proc Natl Acad Sci USA 1990; 87:748-752.

3 Ward KN: The natural history and laboratory diagnosis of human herpesviruses- 6 and -7 infections in the immunocompetent. J Clin Virol 2005;32:183-193.

4 Black JB, Pellett EP: Human herpesvirus-7. Rev Med Virol 1999;9:245-262. 
5 Yamamoto K, Yoshikawa T, Okamoto S, Yamaki K, Shimokata K, Nishiyama Y: HHV-6 and 7 DNA loads in lung tissues collected from patients with interstitial pneumonia. J Med Virol 2005;75:70-75.

6 Ross DJ, Chan RCK, Kubak B, Laks H, Nichols WS: Bronchiolitis obliterans with organizing pneumonia: possible association with human herpesvirus-7 infection after lung transplantation. Transplant Proc 2001;33: 2603-2606.

$\checkmark 7$ Solidoro P, Libertucci D, Delsedime L, Ruffini E, Bosco M, Costa C, Rinaldi M, Baldi S: Combined cytomegalovirus prophylaxis in lung transplantation: effects on acute rejection, lymphocytic bronchitis/bronchiolitis, and herpes virus infections. Transplant Proc 2008;40:2013-2014.

8 Costa C, Libertucci D, Solidoro P, Sinesi F, Bergallo M, Margio S, Piana F, Baldi S, Cavallo R: Rapid shell vial culture for the detection of respiratory viruses from bronchoalveolar lavage in immunocompromised patients. Panminerva Med 2007;9:1-6.

>9 Gruteke P, Glas AS, Dierdorp M, Vreede WB, Pilon JW, Bruisten SM: Practical implementation of a multiplex PCR for acute respiratory tract infections in children. J Clin Microbiol 2004;42:5596-5603.

-10 Arden KE, McErlean P, Nissen MD, Sloots TP, Mackay IM: Frequent detection of human rhinoviruses, paramyxoviruses, coronaviruses, and bocavirus during acute respiratory tract infections. J Med Virol 2006;78: 1232-1240.

- 11 Gerna G, Campanini G, Rovida F, Percivalle E, Sarasini A, Marchi A, Baldanti F: Genetic variability of human coronavirus OC43229E-, and NL63-like strains and their association with lower respiratory tract infections of hospitalized infants and immunocompromised patients. J Med Virol 2006;78: 938-949.
12 Boutolleau D, Duros C, Bonnafous P, Caïola D, Karras A, De Castro N, Ouachée M, Narcy P, Gueudin M, Agut H, Gautheret-Dejean A: Identification of human herpesvirus- 6 variants $A$ and $B$ by primer-specific realtime PCR may help to revisit their respective role in pathology. J Clin Virol 2006;35:257263.

13 Nijhuis M, van Maarseveen N, Schuurman R, Verkuijlen S, de Vos M, Hendriksen K, van Loon AM: Rapid and sensitive routine detection of all members of the genus enterovirus in different clinical specimens by real-time PCR. J Clin Microbiol 2002;40:3666-3670.

14 Gambarino S, Costa C, Elia M, Sidoti F, Mantovani S, Gruosso V, Bergallo M, Cavallo R: Development of a RT real-time PCR for the detection and quantification of human rhinoviruses. Mol Biotechnol 2009;42:350357.

15 Terlizzi ME, Bergallo M, Sidoti F, Sinesi F, Vendrame R, Gambarino S, Costa C, Cavallo R: Quantitative RT real-time PCR and indirect immunofluorescence for the detection of human parainfluenza virus 1,2, 3. J Virol Methods 2009;160:172-177.

16 Schweiger B, Zadow I, Heckler R, Timm H, Pauli G: Application of a fluorogenic PCR assay for typing and subtyping of influenza viruses in respiratory samples. J Clin Microbiol 2000;38:1552-1558.

17 Bergallo M, Costa C, Terlizzi ME, Sidoti F, Margio S, Astegiano S, Ponti R, Cavallo R: Development of a LUX real-time PCR for the detection and quantification of human herpesvirus-7. Can J Microbiol 2009;55:319325.

18 Gerna G, Lilleri D, Rognoni V, Agozzino M, Meloni F, Oggionni T, Pellegrini C, Arbustini E, D’Armini AM: Preemptive therapy for systemic and pulmonary human cytomegalovirus infection in lung transplant recipients. Am J Transplant 2009;9:1142-1150.

-19 Dockrell DH, Paya CV: Human herpesvirus6 and -7 in transplantation. Rev Med Virol 2001;11:23-36.

-20 Humar A, Asberg A, Kumar D, Hartmann A, Moussa G, Jardine A, Rollag H, Mouas H, Gahlemann CG, Pescovitz MD, VICTOR Study Group: An assessment of herpesvirus co-infections in patients with CMV disease: correlation with clinical and virologic outcomes. Am J Transplant 2009;9:374-381.
21 Chan PK, Peiris JS, Yuen KY, Liang RH, Lau YL, Chen FE, Lo SK, Cheung CY, Chan TK, $\mathrm{Ng} \mathrm{MH}$ : Human herpesvirus- 6 and human herpesvirus-7 infections in bone marrow transplant recipients. J Med Virol 1997;53: 295-305.

$>22$ Griffiths PD, Ait-Khaled M, Bearcroft CP, Clark DA, Quaglia A, Davies SE, Burroughs AK, Rolles K, Kidd IM, Knight SM, Noibi SM, Cope AV, Phillips AN, Emery VC: Human herpesviruses- 6 and -7 as potential pathogens after liver transplant: prospective comparison with the effect of cytomegalovirus. J Med Virol 1999;59:496-501.

23 Chan PK, Li CK, Chik KW, Lee V, Shing MMK, Ng KC, Cheung JL, Fok TF, Cheng AF: Risk factors and clinical consequences of human herpesvirus-7 infection in paediatric haematopoietic stem cell transplant recipients. J Med Virol 2004;72:668-674.

24 Lautenschlager I, Lappalainen M, Linnavuori K, Suni J, Hoeckerstedt K: CMV infection is usually associated with concurrent $\mathrm{HHV}$ 6 and HHV-7 antigenemia in liver transplant patients. J Clin Virol 2002;25:S57-S61.

$\checkmark 25$ Razonable RR, Brown RA, Humar A, Covington E, Alecock E, Paya CV, PV16000 Study Group: Herpesvirus infections in solid organ transplant patients at high risk of primary cytomegalovirus disease. J Infect Dis 2005;192:1331-1339.

26 Chapenko S, Folkmane I, Tomsone V, Amerika D, Rozentals R, Murovska M: Co-infection of two $\beta$-herpesviruses (CMV and $\mathrm{HHV}-7$ ) as an increased risk factor for ' $\mathrm{CMV}$ disease' in patients undergoing renal transplantation. Clin Transplantation 2000;14: 486-492.

-27 Manuel O, Kumar D, Moussa G, Chen MH, Pilewski J, McCurry KR, Studer SM, Crespo M, Husain S, Humar A: Lack of association between $\beta$-herpesvirus infection and bronchiolitis obliterans syndrome in lung transplant recipients in the era of antiviral prophylaxis. Transplantation 2009;87:719-725. 